\title{
Nutrient use efficiency in sugarcane cultivars
}

\section{Eficiência de utilização de nutrientes em cultivares de cana-de-açúcar}

\author{
Volmir KIST ${ }^{1}$; Gustavo da SILVEIRA ${ }^{2}$; Paulo Mafra de Almeida COSTA ${ }^{3}$; Mauro Wagner de OLIVEIRA ${ }^{4}$; \\ Márcio Henrique Pereira BARBOSA \\ ${ }^{1}$ Doutor; Universidade Federal de Viçosa; volkist@gmail.com \\ 2 Autor para correspondência; Doutor; Universidade Federal de Viçosa; Departamento de Fitotecnia; CEP.36570-009; \\ Viçosa-Minas Gerais; Brasil; gustavodasilveira.faem@gmail.com \\ ${ }^{3}$ Mestre; Universidade Federal de Viçosa; paulomafra@gmail.com \\ 4 Doutor; Universidade Federal de Alagoas; maurowoliveira@gmail.com \\ ${ }^{5}$ Doutor; Universidade Federal de Viçosa; barbosa@ufv.br
}

Recebido em: 23-01-2014; Aceito em: 25-01-2015

\begin{abstract}
This work aimed at assessing the nutritional efficiency of sugarcane cultivars in plant and first ratoon crop cycles. Eight cultivars were evaluated for the characters nutrient content $(\mathrm{N}, \mathrm{P}, \mathrm{K}, \mathrm{Ca}$ and $\mathrm{Mg})$ accumulated in the leaf $+3\left(L_{+3}\right)$ and in the biomass and productivity of dry matter $(D M)$. Significant differences $(p<0.05)$ between cultivars were observed in almost all variables. The cultivars were separated into two and three groups in function of the nutrient accumulated in $\mathrm{L}_{+3}$ and biomass, respectively, both in plant cane and first ratoon cane. The average productivity of DM was $38 \mathrm{t} \mathrm{ha}^{-1}$ and $27.8 \mathrm{t} \mathrm{ha}^{-1}$ in plant cane and first ratoon, respectively. Only the cultivar RB867515 showed high utilization efficiency for all nutrients accumulated in $\mathrm{L}_{+3}$ in the two cycles. On the other hand, any cultivar exhibited simultaneous high utilization efficiency in the five evaluated nutrients in biomass. The cultivar that showed the best utilization efficiency was RB835486, standing out in four nutrients (N, P, Ca and $\mathrm{Mg}$ ) in the two cycles. However, it was not possible to identify the best cultivars based only on nutrient utilization efficiency.
\end{abstract}

Additional keywords: biomass; dry matter; foliar analysis; Saccharum spp.

\section{Resumo}

O objetivo desse trabalho foi avaliar a eficiência de utilização de nutrientes de cultivares de cana-de-açúcar, via análise foliar e biomassa aérea, em cana-planta e cana-soca. Foram avaliadas oito cultivares para o teor de $\mathrm{N}, \mathrm{P}, \mathrm{K}, \mathrm{Ca}$ e $\mathrm{Mg}$ na folha $+3\left(\mathrm{~L}_{+3}\right)$ e na biomassa aérea e produtividade de matéria seca (MS). Diferenças significativas $(p<0,05)$ entre cultivares foram verificadas na maioria das variáveis. As cultivares foram separadas em dois e três conjuntos em relação aos nutrientes acumulados na $L_{+3}$ e na biomassa aérea, respectivamente, tanto em cana-planta quanto em cana-soca. A produtividade média de MS foi de $38 \mathrm{t} \mathrm{ha}^{-1} \mathrm{e}$ $27,8 \mathrm{t} \mathrm{ha}^{-1}$, em cana-planta e cana-soca, respectivamente. Apenas a cultivar RB867515 apresentou alta eficiência de utilização para todos os nutrientes quantificados na $L_{+3}$, nos dois ciclos. Por outro lado, nenhuma cultivar apresentou simultaneamente alta eficiência de utilização nos cinco nutrientes avaliados na biomassa aérea. A cultivar que apresentou a melhor eficiência de utilização foi a RB835486, destacando-se em quatro nutrientes (N, P, Ca e Mg), simultaneamente em cana-planta e cana-soca. Contudo, não foi possível identificar as cultivares mais produtivas apenas com base na eficiência de utilização nutricional. A recomendação deve ser efetuada também com base no teor de nutrientes acumulados e na produtividade.

Palavras-chave adicionais: análise foliar; biomassa; matéria seca; Saccharum spp.

\section{Introduction}

Sugarcane (Saccharum spp.) is one of the crops of greater economic impact in Brazil. Given the growing existing demand for the main products derived from that culture, such as sugar, ethanol and fiber, increases in crop area and yield are recorded annually (CONAB, 2013). Thus, the search for better varieties adapted to the different environments of cultivation, to the mechanized management practices and responsive to mineral nutrition has been intensified in recent years.
Among the many factors affecting the crop yield, the most important are the cultivar potential, soil fertility, climatic conditions, the incidence of pests and diseases and the cultural practices. Considering that the natural fertility is low in most areas cultivated with sugarcane in the south-central region of the country, the use of chemical fertilizers to increase productivity has become a common practice among producers. However, this practice has also contributed to raise the cost of production, and the excess of applications may cause serious environmental problems. Nitrogen, for example, when applied in excess in 
sandy and poorly structured soils in high rainfall conditions, can easily be lost by leaching, contaminating groundwater and springs (Biggs et al., 2013; Mitchell et al., 2009; Thorburn et al., 2011).

On the other hand, sugarcane cultivars differ on the absorption and use of nutrients (Oliveira et al., 2010; Rengel \& Damon, 2008). Thus, it is possible to select efficient cultivars in use of nutrients, reducing the risks of environmental contamination and, above all, the cost of production. According to Blair (1993), nutritional efficiency is the ability that the cultivar has to incorporate and use the nutrient in the production of economic yield biomass.

Studies on nutritional efficiency in sugarcane are scarce, however, very important due to the significant cultivated area (CONAB, 2013). It should also be noted that sugarcane plantations are usually renewed only after five/six harvests. Thus, the plantation of a cultivar less efficient in the use of nutrients may increase the cost of production and, therefore, reflect in lower profitability.

The nutritional use efficiency is obtained through the relation between the production of economic yield biomass and the nutrient concentration in the plant tissue (Batten, 1992; Luca et al., 2002; Wang et al., 2010; Wissuwa et al., 2009). The nutrient content can be quantitated by chemical analysis of the leaves, or even from the whole plant. In sugarcane, the concentration of nutrients in the leaf tissue is usually determined from the third leaf of visible dewlap $\left(L_{+3}\right)$ at the maximum stage of vegetative development (Gallo et al., 1962; Malavolta \& Gomes, 1962; Mccray et al., 2010). Although more laborious, the nutrient content can also be measured from the chemical analysis of the whole plant when it reaches full maturity stage (Malavolta et al., 1997).

This study aimed to evaluate the use efficiency of nutrients in sugarcane cultivars via foliar analysis and aboveground biomass in cane plant and first ratoon.

\section{Material and methods}

The experiment was conducted in the city of Mercês, Minas Gerais, Brazil (2111'39 "S latitude, 4320'29"W longitude and $522 \mathrm{~m}$ altitude). The soil was classified as a Red-Yellow Argisol with clay texture (Table 1). Soil $\mathrm{pH}$ was of medium magnitude (5.5), and therefore, no acidity correction was applied, because the cation exchange capacity and base saturation level were within the recommended range for the cultivation of sugarcane (Souza et al., 2007).

Table 1 - Granulometric and chemical characteristics of Red-Yellow Argisol, analyzed during the implantation of the experiment.

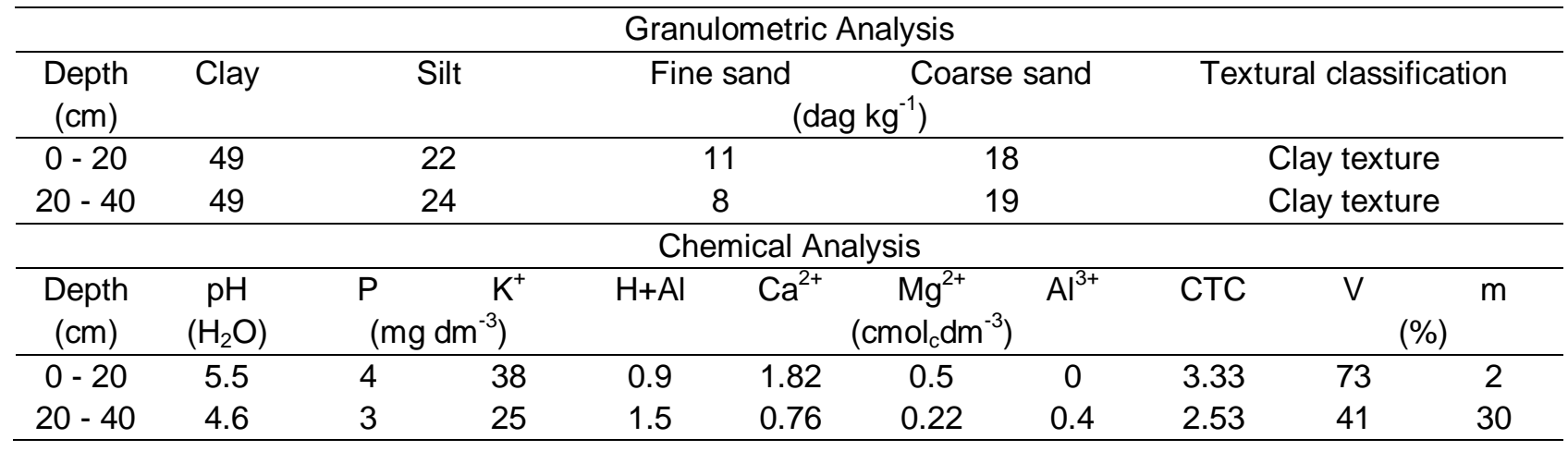

Analyses carried out in the Laboratories of Physical and Chemical Analysis of the Soil, Soil Science Department, UFV, according to the method described by the Brazilian Corporation of Agricultural Research-EMBRAPA (1997).

The experiment was carried out in a completely randomized block design with eight treatments (cultivars) and four replicates, in a year-and-half cane system. The plots consisted of six 10-m long rows, with $1.4 \mathrm{~m}$ between rows and distribution of 18 buds $\mathrm{m}^{-1}$ in the row. The central $8 \mathrm{~m}$ of the four central rows were considered as useful area. Eight varieties of sugarcane were used for the study, which are: RB72454, RB835486, RB855536, RB867515, RB928064, SP80-1816, SP80-1842 and SP80-3280. These cultivars are representative in sugarcane production in Brazil, occupying extensive areas of cultivation. Moreover, they take part as genitors in the main improvement programs (Barbosa et al., 2012). Fertilization was performed in three stages: base ferti- lization- $700 \mathrm{~kg} \mathrm{ha}^{-1}$ of the formula 06-30-06 $\left(\mathrm{N}-\mathrm{P}_{2} \mathrm{O}_{5}-\right.$ $\mathrm{K}_{2} \mathrm{O}$ ) in the row, before planting the sugarcane; covering fertilization - N60 kg ha ${ }^{-1}$ and $\mathrm{K}_{2} \mathrm{O}$ $130 \mathrm{~kg} \mathrm{ha}^{-1}, 240$ days after the implementation of the experiment; and fertilization in first ratoon - application of $170 \mathrm{~kg} \mathrm{ha}^{-1}$ of $\mathrm{N}$ and $210 \mathrm{~kg} \mathrm{ha}^{-1}$ of $\mathrm{K}_{2} \mathrm{O}, 60$ days after the harvest of plant cane (Malavolta et al., 2007). Both in plant cane and in the first ratoon, the fertilizations of $\mathrm{N}$ and $\mathrm{K}$ were made in the form of urea and potassium chloride, respectively. The nutrient replacement was made based on the average export value of nutrients, adjusted to harvest of the abovegroung parts (Malavolta et al., 1997). The weeds were controlled through the application of herbicides and weedings when necessary. 
Foliar sampling and nutritional analyzes were performed as described by Malavolta et al. (1997). The $\mathrm{L}_{+3}$ were harvested when the plants were in full development stage, at 10 months in plant cane and at 7 months in first ratoon cane. Fifteen $L_{+3}$ were randomly collected within the useful portion. After washed with distilled water, the middle third was selected and the midrib was removed. The leaf blades were dried in an oven with forced ventilation $\left(65^{\circ} \mathrm{C}\right)$ until reaching constant mass. Subsequently, the material was ground in a Wiley mill, with a 20 mesh sieve and the samples were analyzed for content of $\mathrm{N}, \mathrm{P}, \mathrm{K}, \mathrm{Ca}$ and $\mathrm{Mg}$.

Plant cane was harvested at 16 months and first ratoon cane at 12 months. It was used the two central rows, which were harvested integrally, i.e, all the plants were cut off at ground level, keeping on them the dry leaves, green leaves and tips. After weighing the total biomass, information used to estimate the variable ton of biomass $\mathrm{ha}^{-1}(\mathrm{TBH})$, a sample of approximately $15 \mathrm{~kg}$ (whole stem with leaves and tips) was triturated in electrical forage. Subsequently, a sample of $500 \mathrm{~g}$ (fresh weight - FW) was subjected to drying in an oven with forced ventilation $\left(65^{\circ} \mathrm{C}\right)$ until reaching constant mass, thereby obtaining the dry matter (DM). The DM, after weighed, was triturated in a Wiley mill, with a 20-mesh sieve. Samples of this material were analyzed for $N, P$, K, Ca and Mg, as described in Malavolta et al. (1997). The variable dry matter ha $^{-1}$ (DM) was obtained by multiplying the $\mathrm{TBH}$ by the coefficient of the ratio $\mathrm{DM} / \mathrm{FW}$. The values of accumulation of nutrients in the aboveground part of sugarcane were obtained by multiplying the concentration values of these elements by the dry biomass values of the aboveground part.

Use efficiencies (UE) of N, P, K, Ca and Mg were estimated by the expressions that follow, which were derived from those presented by Moll et al. (1982): UE Xf $=\mathrm{DM} /$ content $(\mathrm{g} / \mathrm{kg})$ of the nutrient in the $\mathrm{L}_{+3} ; \mathrm{UE} \mathrm{Xb}=$ $=\mathrm{DM} /$ quantity $(\mathrm{kg} / \mathrm{ha})$ of the nutrient in the biomass, where: $X$ = the nutrient under study (N, $P, K, C a$ and $M g$ ).

Data of all variables were subjected to analysis of variance, following a completely randomized block design, according to the split plots in time (plant cane and first ratoon), considering cultivar and harvest as fixed factors. The means were grouped using the Scott-Knott test at 5\% probability. All analyzes were performed using the software GENES (Cruz, 2013).

\section{Results and discussions}

Significant interactions $(p<0.05)$ between cultivars and crops (plant cane and first ratoon) were observed in all variables $(\mathrm{N}, \mathrm{P}, \mathrm{K}, \mathrm{Ca}$ and $\mathrm{Mg}$ quantified in $L_{+3}$ and in biomass, and DM). As a result, individual analyses of variance were conducted to plant cane and first ratoon.

Significant differences $(p<0.05)$ among cultivars were observed for $\mathrm{N}, \mathrm{Ca}$ and $\mathrm{Mg}$ in plant cane and $\mathrm{K}, \mathrm{Ca}$ and $\mathrm{Mg}$ in first ratoon. Despite the significant differences among cultivars for $\mathrm{N}$ in plant cane, means ranging from $12.5-15.3 \mathrm{~g} \mathrm{~kg}^{-1}$ were not separated by the Scott-Knott test (Table 2). For Ca and $\mathrm{Mg}$, means were separated into two groups, although variations have been relatively small (4.5-5.4 and $0.9-1.2 \mathrm{~g} \mathrm{~kg}^{-1}$, respectively). In first ratoon, means of $\mathrm{K}, \mathrm{Ca}$ and $\mathrm{Mg}$ were also separated into two groups, however with larger amplitudes $\left(3.9,1.4\right.$ and $0.7 \mathrm{~g} \mathrm{~kg}^{-1}$, respectively) than the verified in plant cane (Table 2 ).

Comparing the overall means of the nutrient contents quantified in $\mathrm{L}_{+3}$ in plant cane and first ratoon, reductions of $22 \%$ were observed for $\mathrm{P}$ and $\mathrm{K}$, and increases of approximately $45 \%$ for $\mathrm{N}$ and $\mathrm{Ca}$, and $130 \%$ for $\mathrm{Mg}$ (Figure 1). However, these values are within the range considered suitable for the development of the crop and are similar to those reported in the literature (Franco et al., 2011; Malavolta et al., 1997; Reis Junior \& Monnerat, 2003).

Variations in the nutrient content in the $\mathrm{L}_{+3}$ from one cycle to another, as observed in this study, are common in sugarcane. Whereas the ability of nutrient uptake of the cultivars decreases along harvests due to degeneration (Carmo Neto et al., 2011), to reduced management practices of post-harvest soil and to nutritional recovery below the requirement of the crop, it is to expect that the accumulated nutrient content in the leaf is smaller each harvest.

Regarding the $\mathrm{Ca}$ and $\mathrm{Mg}$, no application was made before and during the experiment, but the levels of these nutrients accumulated in the $L_{+3}$ were higher in the first ratoon compared to the plant cane. One of the explanations can be attributed to the main root system of the plant in first ratoon be already established, serving as a nutrient reservoir that can be readily used in the resumption of plant growth after harvests. However, $\mathrm{Ca}$ and $\mathrm{Mg}$ levels obtained in first ratoon are within the range considered adequate by Malavolta et al. (1997).

According to these authors, changes in $\mathrm{Ca}$ content between $8-10 \mathrm{~g} \mathrm{~kg}^{-1}$ in plant cane and $5-7 \mathrm{~g} \mathrm{~kg}^{-1}$ in first ratoon provide a good development to sugarcane. For Mg, they highlight as suitable value a range between $2-3 \mathrm{~g} \mathrm{~kg}^{-1}$, for both production cycles.

It should be stressed that abiotic factors, such as water availability, brightness and temperature, have direct interference in the absorption and use of nutrients by the plants. Due to the high metabolic activity in young leaves of plants that are in full development, any change that happens in any of these factors can directly reflect the content of accumulated nutrients in the leaf, especially those highly mobile nutrients in the plant, like $\mathrm{N}, \mathrm{P}, \mathrm{K}$ and Mg (Rossetto et al., 2008). Another important aspect relates to the translocation of certain nutrients, which normally occurs from older to younger leaves during the vegetative development of plants. In the particular case of sugarcane, this translocation also occurs from mature leaves to the storing tissue (stem) as far as the maturation of plants begins. Thus, it is understandable that changes occur in the content of accumulated nutrients in the leaf over the crop development cycle. 
Table 2 - Average contents of $\mathrm{N}, \mathrm{P}, \mathrm{K}, \mathrm{Ca}$ and $\mathrm{Mg}\left(\mathrm{g} \mathrm{kg}^{-1}\right)$ quantified in leaf +3 and accumulation of nutrients ( $\mathrm{kg} \mathrm{ha}^{-1}$ ) in aboveground biomass in plant cane and first ratoon of eight sugarcane cultivars (Saccharum spp.).

\begin{tabular}{|c|c|c|c|c|c|c|}
\hline \multirow{2}{*}{ Cultivars } & Plant cane & First ratoon & Mean & Plant cane & First ratoon & Mean \\
\hline & \multicolumn{3}{|c|}{$\mathrm{N}\left(\mathrm{q} \mathrm{kq}^{-1}\right)$ in leaf +3} & \multicolumn{3}{|c|}{$\mathrm{N}\left(\mathrm{kg} \mathrm{ha}^{-1}\right)$ in the aboveground biomass } \\
\hline RB72454 & $14.8 \mathrm{Aa}$ & $18.7-\mathrm{a}$ & $16.7 \mathrm{~A}$ & $150.0 \mathrm{Aa}$ & $105.1 \mathrm{Bb}$ & $127.5 \mathrm{~A}$ \\
\hline RB835486 & $15.3 \mathrm{Ab}$ & $20.3-a$ & $17.8 \mathrm{~A}$ & $120.4 \mathrm{Ba}$ & $114.5 \mathrm{Ba}$ & $117.4 \mathrm{~A}$ \\
\hline RB867515 & $13.3 \mathrm{Ab}$ & $19.5-a$ & $16.4 \mathrm{~B}$ & $150.9 \mathrm{Aa}$ & $122.6 \mathrm{Ab}$ & $136.7 \mathrm{~A}$ \\
\hline RB855536 & $14.1 \mathrm{Ab}$ & $20.4-a$ & $17.3 \mathrm{~A}$ & $160.5 \mathrm{Aa}$ & $95.6 \mathrm{Cb}$ & $128.1 \mathrm{~A}$ \\
\hline RB928064 & $13.8 \mathrm{Ab}$ & $20.2-a$ & $17.0 \mathrm{~A}$ & $116.9 \mathrm{Ba}$ & $110.5 \mathrm{Ba}$ & $113.7 \mathrm{~A}$ \\
\hline SP80-1816 & $12.8 \mathrm{Ab}$ & $18.7-\mathrm{a}$ & $15.7 \mathrm{~B}$ & 139.6 Aa & $94.3 \mathrm{Cb}$ & $117.0 \mathrm{~A}$ \\
\hline SP80-1842 & $12.5 \mathrm{Ab}$ & $19.0-\mathrm{a}$ & $16.1 \mathrm{~B}$ & $114.8 \mathrm{Ba}$ & $123.6 \mathrm{Aa}$ & $119.2 \mathrm{~A}$ \\
\hline SP80-3280 & $13.6 \mathrm{Ab}$ & $20.2-a$ & $16.9 \mathrm{~A}$ & $143.2 \mathrm{Aa}$ & $83.5 \mathrm{Db}$ & $113.4 \mathrm{~A}$ \\
\hline Mean & 13.8 & 19.7 & 16.6 & 137.0 & 106.2 & 121.6 \\
\hline \multirow[t]{2}{*}{ CV $(\%)$} & 8.4 & 4.9 & 6.8 & 12.3 & 7.2 & 15.6 \\
\hline & \multicolumn{3}{|c|}{$\mathrm{P}\left(\mathrm{g} \mathrm{kg}^{-1}\right)$ in leaf +3} & \multicolumn{3}{|c|}{$\mathrm{P}\left(\mathrm{kg} \mathrm{ha}^{-1}\right)$ in the aboveground biomass } \\
\hline RB72454 & $1.9-\mathrm{a}$ & $1.3-b$ & $1.6-$ & $39.9 \mathrm{Ba}$ & $25.5 \mathrm{Ab}$ & $32.7 \mathrm{~A}$ \\
\hline RB835486 & $1.9-\mathrm{a}$ & $1.4-b$ & $1.7-$ & $38.3 \mathrm{Ba}$ & $24.8 \mathrm{Ab}$ & $31.6 \mathrm{~A}$ \\
\hline RB867515 & $1.8-\mathrm{a}$ & $1.5-b$ & $1.6-$ & $42.7 \mathrm{Aa}$ & $25.4 \mathrm{Ab}$ & $34.1 \mathrm{~A}$ \\
\hline RB855536 & $1.7-\mathrm{a}$ & $1.4-b$ & $1.6-$ & $39.3 \mathrm{Ba}$ & $22.3 \mathrm{Cb}$ & $30.8 \mathrm{~A}$ \\
\hline RB928064 & $1.8-\mathrm{a}$ & $1.5-b$ & $1.7-$ & $39.3 \mathrm{Ba}$ & $25.1 \mathrm{Ab}$ & $31.9 \mathrm{~A}$ \\
\hline SP80-1816 & $1.8-\mathrm{a}$ & $1.6-b$ & $1.7-$ & $39.4 \mathrm{Ba}$ & $22.9 \mathrm{Cb}$ & $31.2 \mathrm{~A}$ \\
\hline SP80-1842 & $1.8-\mathrm{a}$ & $1.5-b$ & $1.7-$ & $38.3 \mathrm{Ba}$ & $23.8 \mathrm{Bb}$ & $31.0 \mathrm{~A}$ \\
\hline SP80-3280 & $1.8-\mathrm{a}$ & $1.4-b$ & $1.6-$ & $41.2 \mathrm{Aa}$ & $22.4 \mathrm{Cb}$ & $31.8 \mathrm{~A}$ \\
\hline Mean & 1.8 & 1.4 & 1.6 & 39.7 & 24.0 & 31.9 \\
\hline \multirow{2}{*}{ CV $(\%)$} & 4.9 & 10.5 & 8.0 & 3.4 & 3.2 & 12.0 \\
\hline & \multicolumn{3}{|c|}{$\mathrm{K}\left(\mathrm{g} \mathrm{kg}^{-1}\right)$ in leaf +3} & \multicolumn{3}{|c|}{$\mathrm{K}\left(\mathrm{kg} \mathrm{ha}^{-1}\right)$ in the aboveground biomass } \\
\hline RB72454 & $13.9-\mathrm{a}$ & $11.9 \mathrm{Ab}$ & $12.9 \mathrm{~B}$ & $268.5 \mathrm{Aa}$ & $216.8 \mathrm{Ba}$ & $242.7 \mathrm{~A}$ \\
\hline RB835486 & $15.0-\mathrm{a}$ & $13.1 \mathrm{Ab}$ & $14.1 \mathrm{~A}$ & $218.3 \mathrm{Ba}$ & $204.6 \mathrm{Ba}$ & $211.4 \mathrm{~A}$ \\
\hline RB867515 & $12.7-\mathrm{a}$ & $10.4 \mathrm{Bb}$ & $11.5 \mathrm{C}$ & $254.7 \mathrm{Aa}$ & $265.1 \mathrm{Aa}$ & $259.9 \mathrm{~A}$ \\
\hline RB855536 & $13.2-a$ & $9.2 \mathrm{Bb}$ & $11.2 \mathrm{C}$ & $286.4 \mathrm{Aa}$ & $181.9 \mathrm{Cb}$ & $234.2 \mathrm{~A}$ \\
\hline RB928064 & $14.8-a$ & $11.0 \mathrm{Bb}$ & $12.9 \mathrm{~B}$ & $206.5 \mathrm{Ba}$ & $231.2 \mathrm{Ba}$ & $218.9 \mathrm{~A}$ \\
\hline SP80-1816 & $14.0-\mathrm{a}$ & $10.7 \mathrm{Bb}$ & $12.3 \mathrm{~B}$ & 283.3 Aa & $179.6 \mathrm{Cb}$ & $231.5 \mathrm{~A}$ \\
\hline SP80-1842 & $14.4-\mathrm{a}$ & $10.5 \mathrm{Bb}$ & $12.5 \mathrm{~B}$ & $226.5 \mathrm{Ba}$ & $167.1 \mathrm{Cb}$ & $196.8 \mathrm{~A}$ \\
\hline SP80-3280 & $14.2-\mathrm{a}$ & $10.6 \mathrm{Bb}$ & $12.4 \mathrm{~B}$ & $288.4 \mathrm{Aa}$ & $133.1 \mathrm{Db}$ & $210.7 \mathrm{~A}$ \\
\hline Mean & 14.0 & 10.9 & 12.5 & 254.1 & 197.4 & 225.8 \\
\hline \multirow[t]{2}{*}{ CV $(\%)$} & 7.4 & 9.4 & 8.5 & 9.9 & 10.3 & 17.5 \\
\hline & \multicolumn{3}{|c|}{$\mathrm{Ca}\left(\mathrm{g} \mathrm{kg}^{-1}\right)$ in leaf +3} & \multicolumn{3}{|c|}{$\mathrm{Ca}\left(\mathrm{kg} \mathrm{ha}^{-1}\right)$ in the aboveground biomass } \\
\hline RB72454 & $5.4 \mathrm{Ab}$ & $7.4 \mathrm{Aa}$ & $6.4 \mathrm{~A}$ & $156.9 \mathrm{Aa}$ & $56.7 \mathrm{Ab}$ & $106.8 \mathrm{~A}$ \\
\hline RB835486 & $5.3 \mathrm{Ab}$ & $7.0 \mathrm{Ba}$ & $6.2 \mathrm{~A}$ & $125.6 \mathrm{Ca}$ & $52.4 \mathrm{Bb}$ & $89.0 \mathrm{~B}$ \\
\hline RB867515 & $5.3 \mathrm{Ab}$ & 7.7 Aa & $6.5 \mathrm{~A}$ & 153.6 Aa & $63.4 \mathrm{Ab}$ & $108.6 \mathrm{~A}$ \\
\hline RB855536 & $4.5 \mathrm{Bb}$ & $7.6 \mathrm{Aa}$ & $6.1 \mathrm{~A}$ & $161.8 \mathrm{Aa}$ & $38.7 \mathrm{Cb}$ & $100.3 \mathrm{~A}$ \\
\hline RB928064 & 4.9 Ab & 7.7 Aa & $6.3 \mathrm{~A}$ & $116.3 \mathrm{Ca}$ & $50.1 \mathrm{Bb}$ & $83.2 \mathrm{~B}$ \\
\hline SP80-1816 & $5.4 \mathrm{Ab}$ & $6.7 \mathrm{Ba}$ & $6.0 \mathrm{~A}$ & $140.4 \mathrm{Ba}$ & $50.8 \mathrm{Bb}$ & $95.6 \mathrm{~B}$ \\
\hline SP80-1842 & $5.0 \mathrm{Ab}$ & $6.8 \mathrm{Ba}$ & $5.9 \mathrm{~A}$ & $109.8 \mathrm{Ca}$ & $50.0 \mathrm{Bb}$ & $79.9 \mathrm{~B}$ \\
\hline SP80-3280 & $4.5 \mathrm{Bb}$ & $6.3 \mathrm{Ba}$ & $5.4 \mathrm{~B}$ & $145.9 \mathrm{Ba}$ & $40.4 \mathrm{Cb}$ & $93.2 \mathrm{~B}$ \\
\hline Mean & 5.0 & 7.2 & 6.1 & 138.8 & 50.3 & 94.6 \\
\hline \multirow[t]{2}{*}{ CV $(\%)$} & 7.8 & 9.0 & 9.6 & 6.2 & 11.6 & 14.0 \\
\hline & \multicolumn{3}{|c|}{$\mathrm{Mg}\left(\mathrm{g} \mathrm{kg}^{-1}\right)$ in leaf +3} & \multicolumn{3}{|c|}{$\mathrm{Mg}\left(\mathrm{kg} \mathrm{ha}^{-1}\right)$ in the aboveground biomass } \\
\hline RB72454 & $1.1 \mathrm{Ab}$ & $2.7 \mathrm{Aa}$ & $1.9 \mathrm{~A}$ & $39.5 \mathrm{Aa}$ & $30.8 \mathrm{Aa}$ & $35.2 \mathrm{~A}$ \\
\hline RB835486 & $1.0 \mathrm{Ab}$ & $2.2 \mathrm{Ba}$ & $1.6 \mathrm{~B}$ & $27.0 \mathrm{Ba}$ & $21.1 \mathrm{Ba}$ & $24.1 \mathrm{~B}$ \\
\hline RB867515 & $1.1 \mathrm{Ab}$ & $2.4 \mathrm{Aa}$ & $1.7 \mathrm{~A}$ & $37.7 \mathrm{Aa}$ & $30.3 \mathrm{Aa}$ & $34.0 \mathrm{~A}$ \\
\hline RB855536 & $0.9 \mathrm{Bb}$ & $2.5 \mathrm{Aa}$ & $1.7 \mathrm{~A}$ & $36.6 \mathrm{Aa}$ & $17.4 \mathrm{Cb}$ & $27.0 \mathrm{~B}$ \\
\hline RB928064 & $1.2 \mathrm{Ab}$ & $2.1 \mathrm{Ba}$ & $1.6 \mathrm{~B}$ & $28.7 \mathrm{Ba}$ & $24.4 \mathrm{Ba}$ & $26.6 \mathrm{~B}$ \\
\hline SP80-1816 & $1.0 \mathrm{Ab}$ & $2.1 \mathrm{Ba}$ & $1.5 \mathrm{~B}$ & $27.5 \mathrm{Ba}$ & $24.1 \mathrm{Ba}$ & $25.8 \mathrm{~B}$ \\
\hline SP80-1842 & $0.9 \mathrm{Bb}$ & $2.1 \mathrm{Ba}$ & $1.5 \mathrm{~B}$ & $19.5 \mathrm{Ca}$ & $23.6 \mathrm{Ba}$ & $21.6 \mathrm{~B}$ \\
\hline SP80-3280 & $1.2 \mathrm{Ab}$ & 2.0 Ba & $1.6 \mathrm{~B}$ & $28.9 \mathrm{Ba}$ & $23.0 \mathrm{Ba}$ & $26.0 \mathrm{~B}$ \\
\hline Mean & 1.0 & 2.3 & 1.7 & 30.7 & 24.4 & 27.5 \\
\hline CV (\%) & 9.2 & 9.9 & 12.3 & 10.0 & 9.0 & 15.5 \\
\hline
\end{tabular}

$(-)$ Means not separated for not showing significant differences $(p>0.05)$ between treatments. Means followed by the same capital letter in the column and lowercase letter in the line do not differ statistically by the Scott-Knott test at $5 \%$ error probability. 

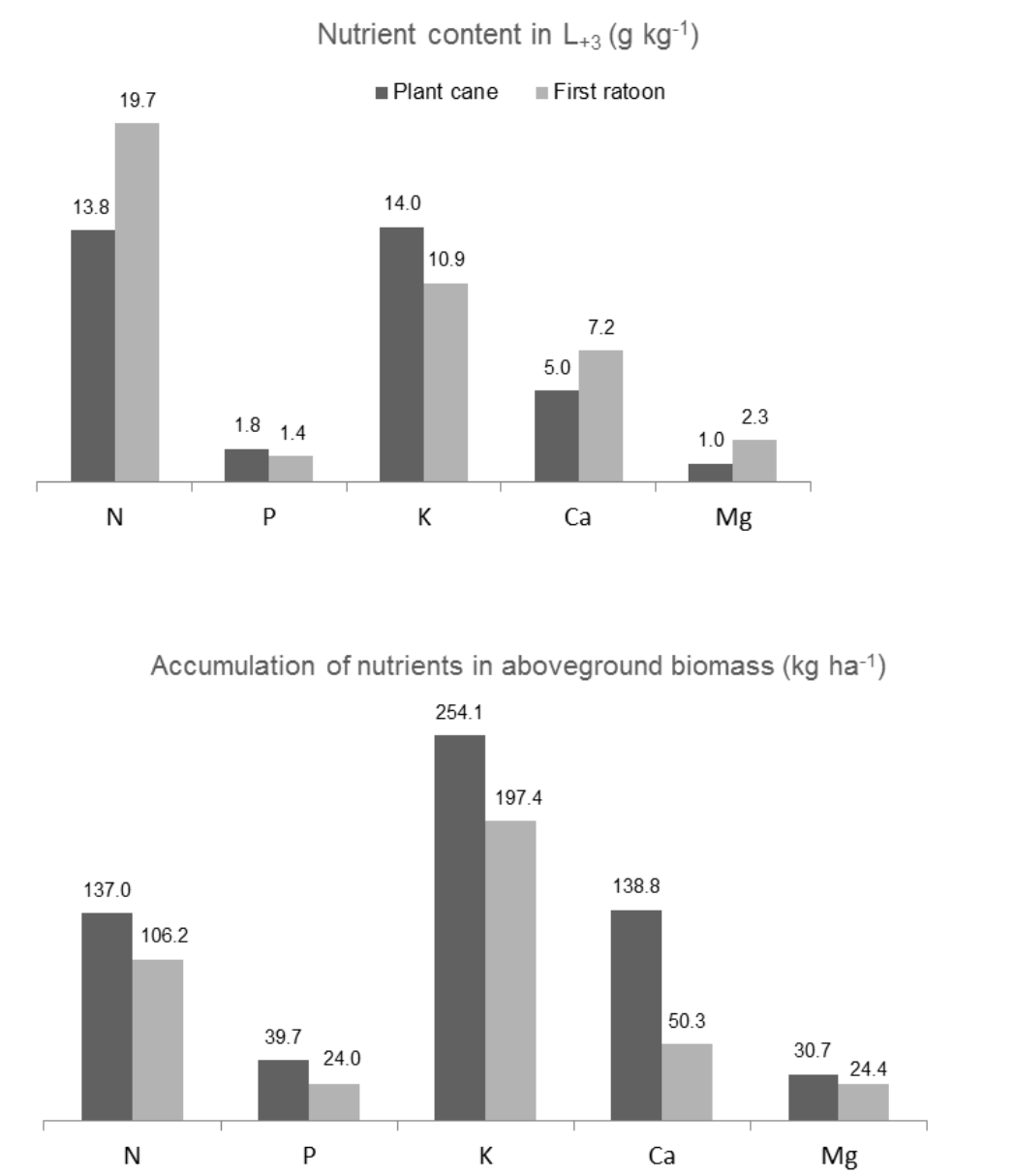

Figure 1 - Average of nutrient content $\left(\mathrm{g} \mathrm{kg}^{-1}\right)$ in leaf +3 and accumulation of nutrients $\left(\mathrm{kg} \mathrm{ha}^{-1}\right)$ in aboveground biomass in plant cane and first ratoon of eight sugarcane cultivars (Saccharum spp.).

Significant differences $(p<0.05)$ among cultivars were observed in all nutrients analyzed in nutrient accumulation in aboveground biomass in plant cane and first ratoon. In plant cane, the means of the nutrients $\mathrm{N}, \mathrm{P}$ and $\mathrm{K}$, which respectively showed variations between 115-161, 38-43 and 207$288 \mathrm{~kg} \mathrm{ha}^{-1}$, were separated into two groups (Table 2). For $\mathrm{Ca}$ and $\mathrm{Mg}$, the means ranged between 110162 and $20-40 \mathrm{~kg} \mathrm{ha}^{-1}$, respectively, and were divided into three groups. In first ratoon, the treatment means in all nutrients $(\mathrm{N}, \mathrm{P}, \mathrm{K}, \mathrm{Ca}$ and $\mathrm{Mg}$ ) were separated into three groups: 84-124, 22-26, 133-265, 39-63 and $17-31 \mathrm{~kg} \mathrm{ha}^{-1}$, respectively.

Considering the overall means of the contents of accumulated nutrients in the aboveground biomass, it is observed that there was a reduction of plant cane and first ratoon of approximately $22 \%$ for $\mathrm{N}, \mathrm{K}$ and $\mathrm{Mg}, 40 \%$ for $\mathrm{P}$ and $65 \%$ for $\mathrm{Ca}$ (Figure 1 ). Of course, when there is no sudden change in weather conditions and nutritional replacement of the cane fields, it is expected that each harvest the content of accumulated nutrients in the biomass decreases gradually as it happens with productivity (Carmo Neto et al., 2011). When the nutritional re- placements are not performed or are not in adequate amounts, as it happened to $\mathrm{P}$ and $\mathrm{Ca}$ in this study, reductions in nutrient content from one cycle to another tend to be even higher due to the export of nutrients that occurs with the harvest (Oliveira et al., 2010).

Significant differences $(p<0.05)$ among cultivars were observed for DM in plant cane and first ratoon. The means were 38.0 and $27.8 \mathrm{t} \mathrm{ha}^{-1}$ with variations between 30.3-43.3 $\mathrm{t} \mathrm{ha}$ and 22.5$33.2 \mathrm{t} \mathrm{ha}^{-1}$, in plant cane and first ratoon, respectively (Table 3).

Considering the mean of the two harvests, it is observed that the cultivar RB867515 was the one that produced more DM, reaching $38.3 \mathrm{t} \mathrm{ha}^{-1}$. Similar values were reported by Oliveira et al. (2004), who obtained means ranging from 35-44 $\mathrm{tha}^{-1}$, based on the evaluation of three cultivars in plant cane in the state of Paraná (PR).

Although the yield reduction from plant cane to first ratoon is common, the reduction achieved in this study was quite pronounced, reaching close to $30 \%$. This process is associated with the genetic characteristics of cultivars and the genotype $x$ 
environment interactions (Silveira et al., 2012; Silveira et al., 2013). Environmental factors related to plant growth, such as temperature, light, water and availability of mineral nutrients (Lima et al., 2006), and intrinsic factors of the cultivar, such as budburst, tillering capacity, age and activity of the root system, also interfere with the reduced productivity from a harvest to another (DinardoMiranda et al., 2008).

Table 3 - Dry matter (DM) yield in plant cane and first ratoon and average of the two harvests of eight sugarcane cultivars (Saccharum spp.).

\begin{tabular}{lccc}
\hline \multirow{2}{*}{ Cultivars } & Plant cane & \multicolumn{1}{c}{ First ratoon } & Mean \\
\cline { 2 - 4 } & & $\mathrm{DM}_{\left(\mathrm{t} \mathrm{ha}^{-1}\right)}$ \\
\hline RB72454 & $39.6 \mathrm{Aa}$ & $27.7 \mathrm{Bb}$ & $33.6 \mathrm{~B}$ \\
RB835486 & $36.9 \mathrm{Aa}$ & $30.9 \mathrm{Aa}$ & $33.9 \mathrm{~B}$ \\
RB867515 & $43.3 \mathrm{Aa}$ & $33.2 \mathrm{Ab}$ & $38.3 \mathrm{~A}$ \\
RB855536 & $42.4 \mathrm{Aa}$ & $22.5 \mathrm{Cb}$ & $32.5 \mathrm{~B}$ \\
RB928064 & $33.9 \mathrm{Ba}$ & $25.7 \mathrm{Bb}$ & $29.8 \mathrm{~B}$ \\
SP80-1816 & $37.3 \mathrm{Aa}$ & $27.7 \mathrm{Bb}$ & $32.5 \mathrm{~B}$ \\
SP80-1842 & $30.3 \mathrm{Ba}$ & $30.2 \mathrm{Aa}$ & $30.2 \mathrm{~B}$ \\
SP80-3280 & $40.2 \mathrm{Aa}$ & $24.7 \mathrm{Cb}$ & $32.4 \mathrm{~B}$ \\
Mean & 38.0 & 27.8 & 32.9 \\
CV (\%) & 9.7 & 7.8 & 12.9 \\
\hline
\end{tabular}

Values followed by the same capital letter in the column and the same lowercase letter in the line do not differ statistically by the Scott-Knott test at $5 \%$ error probability.

Significant differences $(p<0.05)$ among cultivars were observed in all UE, for all studied nutrients $(\mathrm{N}, \mathrm{P}, \mathrm{K}, \mathrm{Ca}, \mathrm{Mg})$ in plant cane and first ratoon (Table 4). Except for $\mathrm{K}$, which in plant cane provided the formation of three groups of cultivars, in all other nutrients ( $\mathrm{N}, \mathrm{P}, \mathrm{Ca}$ and $\mathrm{Mg}$ ) only two groups were formed, considering the two harvests (Table 4).

Among all the cultivars evaluated in plant cane, only RB867515 and RB855536 always integrated the group of higher UE of nutrients, in all nutrients, therefore standing out as the most efficient in nutrient use. On the other hand, the cultivars RB835486, RB928064 and SP80-1842 have always been part of the group with lower mean in all nutrients. However, in first ratoon, in general, the cultivars showed UE distinct from the ones presented in the plant cane. The cultivar RB855536, for example, that in plant cane proved to be one of the most efficient, in first ratoon joined the group of less efficient cultivars for all nutrients. On the other hand, the cultivar SP80-1842 that was always in the group of lower efficiency in plant cane, in first ratoon became part of the group of the most efficient cultivars. Considering plant cane and first ratoon, only cultivar RB867515 remained in the group of higher UE.

Considering the average of the two harvests (Table 4), there was no significant difference ( $p>0.05$ ) among the cultivars for the UE of the nutrients, except for N and K, but only the cultivar RB867515 was different from the others. Thus, the RB867515 can be highlighted as the cultivar with the best overall UE.

Nutrient UE indices of all cultivars in plant cane were higher than in first ratoon for all nutrients. This result can be attributed to higher DM yield of the cultivars in plant cane compared to first ratoon (Table 3). Otherwise, the content of all nutrients (N, P, $\mathrm{K}, \mathrm{Ca}, \mathrm{Mg}$ ) accumulated in the leaf tissue in plant cane should be lower than the content accumulated in the leaf tissue in first ratoon, which did not occur. In this case, it is clear that DM production is not influenced only by the availability and use of nutrients, but by other factors, among them, the yield potential of cultivars and plant health.

Significant differences $(p<0.05)$ among cultivars were observed in all nutrients studied in plant cane and first ratoon, although the means of the cultivars for some nutrients $(\mathrm{N}, \mathrm{P}$ and $\mathrm{Ca}$ in plant cane, $\mathrm{Ca}$ in first ratoon, $\mathrm{P}$ and $\mathrm{Ca}$ in the mean of the two cuttings) have not been separated by the ScottKnott test (Table 4). For $\mathrm{K}$ and $\mathrm{Mg}$ in plant cane, means were separated into two groups. In these two nutrients, only RB867615 is part of the group of cultivars with higher mean.

In first ratoon, two groups of means in nutrients $\mathrm{N}, \mathrm{P}$ and $\mathrm{Ca}$ were formed, and three groups for $\mathrm{K}$. Although there was significant difference among the treatments, means of use efficiency of $\mathrm{Ca}$ were not separated. As shown on Table 4, any cultivar was highly efficient in the use of the five nutrients. Particular emphasis should be given to cultivars RB835486 (N, P, Ca and Mg) and SP801842 ( $\mathrm{P}, \mathrm{K}, \mathrm{Ca}$ and $\mathrm{Mg}$ ), which stood out due to their high means of efficiency in four nutrients each. On the other hand, the negative highlight was the cultivar RB928064, which was always part of the group of lower efficiency. The other cultivars showed varying behavior for use efficiency of the different nutrients. 
Table 4 - Use efficiency (UE) of N, P, K, Ca and Mg quantified in leaf +3 (f) and in aboveground biomass (b) in plant cane and first ratoon, and mean of the two harvests in eight sugarcane cultivars (Saccharum spp.).

\begin{tabular}{|c|c|c|c|c|c|c|}
\hline \multirow{2}{*}{ Cultivars } & Plant cane & First ratoon & Mean & Plant cane & First ratoon & Mean \\
\hline & \multicolumn{3}{|c|}{ UE-N } & \multicolumn{3}{|c|}{ UE- $\mathrm{N}_{\mathrm{b}}$} \\
\hline$\overline{R B 72454}$ & $26.9 \mathrm{Ba}$ & $14.9 \mathrm{Ab}$ & $20.9 B$ & $0.27 \mathrm{Aa}$ & $0.26 \mathrm{Aa}$ & $0.27 \mathrm{~A}$ \\
\hline RB835486 & $24.3 \mathrm{Ba}$ & $15.2 \mathrm{Ab}$ & $19.8 B$ & $0.31 \mathrm{Aa}$ & $0.27 \mathrm{Aa}$ & $0.29 \mathrm{~A}$ \\
\hline RB867515 & $32.7 \mathrm{Aa}$ & $17.1 \mathrm{Ab}$ & $24.9 \mathrm{~A}$ & $0.29 \mathrm{Aa}$ & $0.27 \mathrm{Aa}$ & $0.28 \mathrm{~A}$ \\
\hline RB855536 & 30.3 Aa & $11.1 \mathrm{Bb}$ & $20.7 B$ & $0.27 \mathrm{Aa}$ & $0.24 \mathrm{Ba}$ & $0.25 B$ \\
\hline RB928064 & $24.7 \mathrm{Ba}$ & $12.8 \mathrm{Bb}$ & 18.7B & $0.29 \mathrm{Aa}$ & $0.23 \mathrm{Bb}$ & $0.26 \mathrm{~B}$ \\
\hline SP80-1816 & $29.1 \mathrm{Aa}$ & $14.9 \mathrm{Ab}$ & $22.0 \mathrm{~B}$ & $0.27 \mathrm{Aa}$ & $0.29 \mathrm{Aa}$ & $0.28 \mathrm{~A}$ \\
\hline SP80-1842 & $24.3 \mathrm{Ba}$ & $15.4 \mathrm{Ab}$ & $19.9 B$ & $0.26 \mathrm{Aa}$ & $0.25 \mathrm{Ba}$ & $0.25 B$ \\
\hline SP80-3280 & $29.7 \mathrm{Aa}$ & $12.2 \mathrm{Bb}$ & $20.9 B$ & $0.28 \mathrm{Aa}$ & $0.30 \mathrm{Aa}$ & $0.29 \mathrm{~A}$ \\
\hline Mean & 27.7 & 14.2 & 21.0 & 0.28 & 0.26 & 0.27 \\
\hline \multirow[t]{2}{*}{ CV (\%) } & 10.8 & 10.6 & 14.1 & 1.60 & 2.39 & 1.64 \\
\hline & \multicolumn{3}{|c|}{ UE-P $P_{f}$} & \multicolumn{3}{|c|}{ UE- $P_{b}$} \\
\hline RB72454 & $213.4 \mathrm{Aa}$ & $221.4 \mathrm{Ab}$ & $217.4 \mathrm{~A}$ & $1.00 \mathrm{Aa}$ & $1.09 \mathrm{Ba}$ & $1.05 \mathrm{~A}$ \\
\hline RB835486 & 194.7Ba & 218.7 Ab & $206.7 \mathrm{~A}$ & $0.96 \mathrm{Ab}$ & $1.24 \mathrm{Aa}$ & $1.10 \mathrm{~A}$ \\
\hline RB867515 & $241.3 \mathrm{Aa}$ & $231.9 \mathrm{Ab}$ & $236.6 \mathrm{~A}$ & $1.02 \mathrm{Ab}$ & $1.31 \mathrm{Aa}$ & $1.17 \mathrm{~A}$ \\
\hline RB855536 & $248.6 \mathrm{Aa}$ & 160.1 Bb & $204.4 \mathrm{~A}$ & $1.09 \mathrm{Aa}$ & $1.01 \mathrm{Ba}$ & $1.05 \mathrm{~A}$ \\
\hline RB928064 & 184.1 $\mathrm{Ba}$ & 176.1 Bb & $180.1 \mathrm{~A}$ & $0.89 \mathrm{Aa}$ & $1.03 \mathrm{Ba}$ & $0.96 \mathrm{~A}$ \\
\hline SP80-1816 & $206.6 \mathrm{Ba}$ & $173.7 \mathrm{Bb}$ & $190.2 \mathrm{~A}$ & $0.95 \mathrm{Aa}$ & $1.21 \mathrm{Aa}$ & $1.08 \mathrm{~A}$ \\
\hline SP80-1842 & $166.5 \mathrm{Ba}$ & $204.9 \mathrm{Ab}$ & $185.7 \mathrm{~A}$ & $0.80 \mathrm{Ab}$ & $1.27 \mathrm{Aa}$ & $1.04 \mathrm{~A}$ \\
\hline SP80-3280 & $223.1 \mathrm{Aa}$ & 172.7 Bb & $197.9 \mathrm{~A}$ & $0.98 \mathrm{Aa}$ & $1.10 \mathrm{Ba}$ & $1.04 \mathrm{~A}$ \\
\hline Mean & 209.8 & 194.9 & 202.4 & 0.96 & 1.16 & 1.06 \\
\hline \multirow[t]{2}{*}{ CV (\%) } & 12.4 & 14.5 & 16.5 & 8.71 & 11.42 & 5.99 \\
\hline & \multicolumn{3}{|c|}{ UE-K $K_{f}$} & \multicolumn{3}{|c|}{ UE-K } \\
\hline RB72454 & $28.6 \mathrm{Ba}$ & $23.3 \mathrm{Bb}$ & $26.0 B$ & $0.15 \mathrm{Ba}$ & $0.13 \mathrm{Ca}$ & $0.14 \mathrm{~B}$ \\
\hline RB835486 & $24.8 \mathrm{Ca}$ & $23.9 \mathrm{Bb}$ & $24.3 B$ & $0.17 \mathrm{Aa}$ & $0.15 \mathrm{Ba}$ & $0.16 \mathrm{~A}$ \\
\hline RB867515 & $34.3 \mathrm{Aa}$ & $32.2 \mathrm{Ab}$ & $33.3 \mathrm{~A}$ & $0.17 \mathrm{Aa}$ & $0.13 \mathrm{Ca}$ & $0.15 \mathrm{~A}$ \\
\hline RB855536 & $32.1 \mathrm{Aa}$ & $24.7 \mathrm{Bb}$ & $28.4 \mathrm{~B}$ & $0.15 \mathrm{Ba}$ & $0.12 \mathrm{Ca}$ & $0.14 \mathrm{~B}$ \\
\hline RB928064 & $22.9 \mathrm{Ca}$ & $23.6 \mathrm{Bb}$ & $23.3 B$ & $0.16 \mathrm{Aa}$ & $0.11 \mathrm{Ca}$ & $0.14 \mathrm{~B}$ \\
\hline SP80-1816 & $26.9 \mathrm{Ba}$ & $26.1 \mathrm{Bb}$ & $26.5 B$ & $0.13 \mathrm{Ba}$ & $0.16 \mathrm{Ba}$ & $0.14 \mathrm{~B}$ \\
\hline SP80-1842 & $21.0 \mathrm{Ca}$ & $28.9 \mathrm{Ab}$ & $25.0 \mathrm{~B}$ & $0.13 \mathrm{Ba}$ & $0.18 \mathrm{Aa}$ & $0.16 \mathrm{~A}$ \\
\hline SP80-3280 & $28.3 \mathrm{Ba}$ & $23.3 \mathrm{Bb}$ & $25.8 \mathrm{~B}$ & $0.14 \mathrm{Ba}$ & $0.19 \mathrm{Aa}$ & $0.16 \mathrm{~A}$ \\
\hline Mean & 27.4 & 25.8 & 26.6 & 0.15 & 0.15 & 0.15 \\
\hline \multirow[t]{2}{*}{ CV (\%) } & 10.1 & 11.8 & 13.9 & 1.60 & 2.88 & 0.99 \\
\hline & \multicolumn{3}{|c|}{ UE-Ca $a_{f}$} & \multicolumn{3}{|c|}{ UE-Ca $a_{b}$} \\
\hline RB72454 & $74.1 \mathrm{Ba}$ & $37.7 \mathrm{Ab}$ & $55.9 \mathrm{~A}$ & $0.25 \mathrm{Ab}$ & $0.50 \mathrm{Aa}$ & $0.37 \mathrm{~B}$ \\
\hline RB835486 & $69.9 \mathrm{Ba}$ & $44.4 \mathrm{Ab}$ & $57.1 \mathrm{~A}$ & $0.29 \mathrm{Ab}$ & $0.59 \mathrm{Aa}$ & $0.44 \mathrm{~A}$ \\
\hline RB867515 & 83.0 Aa & $43.8 \mathrm{Ab}$ & $63.4 \mathrm{~A}$ & $0.28 \mathrm{Ab}$ & $0.53 \mathrm{Aa}$ & $0.41 \mathrm{~A}$ \\
\hline RB855536 & $93.5 \mathrm{Aa}$ & $29.7 \mathrm{Bb}$ & $61.6 \mathrm{~A}$ & $0.26 \mathrm{Ab}$ & $0.59 \mathrm{Aa}$ & $0.43 \mathrm{~A}$ \\
\hline RB928064 & $68.9 \mathrm{Ba}$ & $33.5 \mathrm{Bb}$ & $51.2 \mathrm{~A}$ & $0.29 \mathrm{Ab}$ & $0.52 \mathrm{Aa}$ & $0.41 \mathrm{~A}$ \\
\hline SP80-1816 & $70.3 \mathrm{Ba}$ & $41.9 \mathrm{Ab}$ & $56.1 \mathrm{~A}$ & $0.27 \mathrm{Ab}$ & $0.55 \mathrm{Aa}$ & $0.41 \mathrm{~A}$ \\
\hline SP80-1842 & $60.7 \mathrm{Ba}$ & $44.7 \mathrm{Ab}$ & $52.7 \mathrm{~A}$ & $0.28 \mathrm{Ab}$ & $0.61 \mathrm{Aa}$ & $0.44 \mathrm{~A}$ \\
\hline SP80-3280 & $91.2 \mathrm{Aa}$ & $39.2 \mathrm{Ab}$ & $65.2 \mathrm{~A}$ & $0.28 \mathrm{Ab}$ & $0.61 \mathrm{Aa}$ & $0.44 \mathrm{~A}$ \\
\hline Mean & 76.4 & 39.4 & 57.9 & 0.28 & 0.56 & 0.42 \\
\hline \multirow[t]{2}{*}{ CV (\%) } & 14.3 & 12.8 & 19.5 & 1.41 & 4.30 & 2.42 \\
\hline & \multicolumn{3}{|c|}{ UE-Mg } & \multicolumn{3}{|c|}{ UE-Mg } \\
\hline RB72454 & $347.8 \mathrm{Ba}$ & $105.2 \mathrm{Bb}$ & $226.5 \mathrm{~A}$ & $1.00 \mathrm{Ba}$ & $0.91 \mathrm{Ba}$ & $0.95 \mathrm{~B}$ \\
\hline RB835486 & $359.9 \mathrm{Ba}$ & $141.2 \mathrm{Ab}$ & $250.5 \mathrm{~A}$ & $1.37 \mathrm{Aa}$ & $1.47 \mathrm{Aa}$ & $1.42 \mathrm{~A}$ \\
\hline RB867515 & $401.9 \mathrm{Aa}$ & $140.5 \mathrm{Ab}$ & $271.2 \mathrm{~A}$ & $1.16 \mathrm{Ba}$ & $1.10 \mathrm{Ba}$ & $1.13 \mathrm{~B}$ \\
\hline RB855536 & $463.9 \mathrm{Aa}$ & $91.5 \mathrm{Bb}$ & $277.7 \mathrm{~A}$ & $1.17 \mathrm{Ba}$ & $1.31 \mathrm{Aa}$ & $1.24 \mathrm{~B}$ \\
\hline RB928064 & $293.3 \mathrm{Ba}$ & 123.7 Ab & $208.5 \mathrm{~A}$ & $1.19 \mathrm{Ba}$ & $1.06 \mathrm{Ba}$ & $1.12 \mathrm{~B}$ \\
\hline SP80-1816 & $380.4 \mathrm{Ba}$ & 133.1 Ab & $256.8 \mathrm{~A}$ & $1.37 \mathrm{Aa}$ & $1.15 \mathrm{Ba}$ & $1.26 \mathrm{~B}$ \\
\hline SP80-1842 & $328.7 \mathrm{Ba}$ & 146.2 Ab & $237.3 \mathrm{~A}$ & $1.58 \mathrm{Aa}$ & $1.28 \mathrm{Aa}$ & $1.43 \mathrm{~A}$ \\
\hline SP80-3280 & $368.8 \mathrm{Ba}$ & $122.8 \mathrm{Ab}$ & $245.8 \mathrm{~A}$ & $1.41 \mathrm{Aa}$ & $1.09 \mathrm{Ba}$ & $1.25 \mathrm{~B}$ \\
\hline Mean & 368.0 & 36.1 & 246.8 & 1.28 & 1.17 & 1.23 \\
\hline CV (\%) & 13.0 & 13.4 & 19.0 & 18.36 & 17.45 & 15.94 \\
\hline
\end{tabular}

Values followed by the same capital letter in the column and the same lowercase letter in the line do not differ statistically by the Scott-Knott test at $5 \%$ error probability. 
Considering the mean of the two harvests, it was observed that only the means of efficiency of $P$ were not separated. For the other nutrients $(\mathrm{N}, \mathrm{K}, \mathrm{Ca}$ and $\mathrm{Mg}$ ), means were separated into two groups. Only RB835486 showed high efficiency in the five nutrients. The varieties RB867515, SP80-1842 and SP80-3280 also showed good performance, with emphasis on four nutrients each. The other cultivars showed different behavior in the use efficiency of several nutrients.

When comparing the use efficiencies of plant cane and first ratoon, it can be seen that the difference between the two harvests was small, though significant. The greatest difference was observed in $\mathrm{Ca}$, where the use efficiency in plant cane was lower than in first ratoon, in all cultivars.

Identifying cultivars efficient in the use of nutrients is essential for conducting economically viable crops. Furthermore, it is important to know the amount of required nutrients (absorbed and accumulated) by these efficient cultivars. This is because a cultivar can be efficient, but require high contents of nutrients.

Ecologically, preference should be given to the cultivation of highly efficient cultivars in nutrient use, however, with low nutrient requirement. On the other hand, there is no guarantee that these cultivars are highly productive. Economically, preference should be given to the growth of cultivars with high yield potential, however, efficient in use of nutrients, even if the required nutrient content is high. Through this strategy it would be possible to increase the yield per unit of cultivated area and not only maximize productivity due to the nutrient content applied to the culture.

Within this logic, it is possible to indicate some cultivars. The RB867515 accumulated higher N content in the aboveground biomass than the RB928064 in plant cane (Table 2); it also showed higher yield of DM (Table 3). However, the two cultivars showed the same use efficiencies of $\mathrm{N}$ (Table 4). Even accumulating greater amount of $\mathrm{N}$ than RB928064, preference should be given to the cultivation of RB867515 for providing higher yield of DM.

The cultivar RB867515 accumulated higher $P$ content in the aboveground biomass than the RB855536 (Table 2), however, they had the same productivity of DM (Table 3) and the same use efficiencies of $P$ in plant cane (Table 4). In this case, priority should be given to the cultivar with lower nutritional requirement/accumulation, therefore, to the RB855536.

Finally, a different situation from those presented above was observed between the cultivars RB928064 and SP80-1842. They showed the same $\mathrm{Ca}$ content accumulated in the aboveground biomass in plant cane (Table 2), different productivities of DM and the same use efficiency of Ca (Table 4). In this case, the advantage is of the SP80-1842, which showed the highest productivity.

These three scenarios were presented to show that the recommendation of a cultivar cannot be made based solely on the content of accumulated nutrients, or only for productivity and least of all only by the use efficiency of nutrients. The results of this study show that these three characteristics must be simultaneously analyzed so that economically viable crops can be conducted. In addition, different rates of fertilizers can be used for different cultivars without compromising productivity. Finally, it should also be emphasized that the relations between nutrient content in the tissue of sugarcane plant $\left(\mathrm{L}_{+3}\right.$ and aboveground biomass), productivity of DM and nutrient use efficiency of the same cultivar are seldom maintained from a cycle (plant cane) to another (first ratoon). Thus, fertilization should be adjusted every cycle so that better economic yields are obtained.

\section{Conclusions}

Although any cultivar was highly efficient in the use of the five nutrients in the two crop cycles, RB867515 and RB835486 can be highlighted as more efficient cultivars and RB928064 as less efficient in the average of the two cycles.

The nutrient use efficiency cannot be used as the sole criterion for indicating the growth of a cultivar. The recommendation should be made based on the content of nutrients, nutrient use efficiency and productivity.

The nutrient use efficiency estimated from the nutrients concentration in the leaf $\left(L_{+3}\right)$ shows low consistency between plant cane and first ratoon.

\section{References}

Batten GD (1992) A review of phosphorus efficiency in wheat. Plant and Soil 146(1-2):163-168.

Barbosa MHP, Resende MDV, Dias LAS, Barbosa GVS, Oliveira RA, Peternelli LA, Daros E (2012) Genetic improvement of sugar cane for bioenergy: the Brazilian experience in network research with RIDESA. Crop Breeding and Applied Biotechnology 12:87-98.

Biggs J, Thorburn P, Crimp S, Masters B, Attard S (2013) Interactions between climate change and sugarcane management systems for improving water quality leaving farms in the Mackay Whitsunday region, Australia. Agriculture, Ecosystems \& Environment 180:79-89.

Blair G (1993) Nutrient efficiency what do we really mean? In: Randall, PJ et al. (ed) Genetic Aspects of Plant Mineral Nutrition, Dordrecht: Kluwer Academic. p.205-213.

Carmo Neto OV, Lui JJ, Pires LPM, Cancellier LL, Peluzio JM (2011) Desempenho de genótipos de cana-de-açúcar em três cortes na região sul do estado do Tocantins. Revista Verde 6(4):19-27. 
CONAB (2013) Acompanhamento de safra brasileira: cana-de-açúcar. Disponível em: <http://www.conab.gov.br/OlalaCMS/uploads/arquivos/ 13_04_09_10_29_31_boletim_cana_portugues_abril_ 2013_10_lev.pdf> (Acesso em 20 ago 2013)

Cruz CD (2013) GENES - a software package for analysis in experimental statistics and quantitative genetics. Acta Scientiarum. Agronomy 35(3):271-276.

Dinardo-Miranda LL, Vasconcelos ACM, Landell MGA (2008) Cana-de-açúcar. Campinas: Instituto Agronômico de Campinas. 882p.

Franco HCJ, Otto R, Faroni CE, Vitti AC, Almeida de Oliveira EC, Trivelin PCO (2011) Nitrogen in sugarcane derived from fertilizer under Brazilian field conditions. Field Crops Research 121(1):29-41.

Gallo JR, Alvarez R, Abramides E (1962) Amostragem de cana-de-açúcar para fins de análise foliar. Bragantia 21:899-921.

Lima SAA, Silva IF, Santiago RD, Neto LF, Souza C, Cavalcante FS (2006) Influência da adubação mineral sobre três cultivares de cana-de-açúcar na microrregião de Guarabira na Paraíba. Agropecuária Técnica 27(2):92-99.

Luca EF, Boaretto AE, Muraoka T, Chitolina JC (2002) Eficiência de absorção e utilização de fosforo $\left.{ }^{32} \mathrm{P}\right)$ por mudas de eucalipto e arroz. Scientia Agricola 59(3):543-547.

Malavolta E, Vitti GC, Oliveira AS (1997) Avaliação do estado nutricional das plantas: Princípios e aplicações. Piracicaba POTAFOS. 319p.

Malavolta E, Gomes FP (1962) Foliar diagnosis in Brazil. In: Reuther W (ed). Plant analysis and fertilizer problems. Washington, DC: Am. Inst. Biol. Sci. p.232245.

Mccray JM, Ji S, Powell G, Montes G, Perdomo R (2010) Sugarcane Response to DRIS-Based Fertilizer Supplements in Florida. Journal of Agronomy and Crop Science 196(1):66-75.

Mitchell A, Reghenzani J, Faithful J, Furnas M, Brodie J (2009) Relationships between land use and nutrient concentrations in streams draining a'wet-tropics' catchment in northern Australia. Marine and Freshwater Research 60(11):1097-1108.

Moll RH, Kamprath EJ, Jackson WA (1982) Analysis and interpretation of factors which contribute to efficiency of nitrogen utilization. Agronomy Journal 74(3):562-564.
Oliveira ECA, Freire FJ, Oliveira RI, Freire MBGS, Simões Neto DE, Silva AM (2010) Extração e exportação de nutrientes por variedades de cana-deaçúcar cultivadas sob irrigação plena. Revista Brasileira de Ciência do Solo 34:1343-1352.

Oliveira RAD, Daros E, Zambon JLC, Weber H, Ido OT, Zuffellato-Ribas KC, Koehler HS, da Silva DKT (2004) Crescimento e desenvolvimento de três cultivares de cana-de-açúcar no Estado do Paraná. Scientia Agraria 5(1):87-94.

Reis Junior RA, Monnerat PH (2003) Dris norms validation for sugarcane crop. Pesquisa Agropecuaria Brasileira 38(3):379-385.

Rengel Z, Damon PM (2008) Crops and genotypes differ in efficiency of potassium uptake and use. Physiologia Plantarum 133(4):624-636.

Rossetto R, Dias FLF, Vitti AC, Tavares SI (2008) Potássio. In: Dinardo-Miranda, LL et al. (ed). Cana-deaçúcar. Campinas: Instituto Agronômico. 882p.

Silveira LCl, Kist V, de Paula TOM, Barbosa MHP, Oliveira R, Daros E (2012) Adaptabilidade e estabilidade fenotípica de genótipos de cana-deaçúcar no estado de Minas Gerais. Ciência Rural 42(4):587-593.

Silveira LCl, Kist V, Paula TOM, Barbosa MHP, Peternelli LA, Daros E (2013) AMMI analysis to evaluate the adaptability and phenotypic stability of sugarcane genotypes. Scientia Agricola 70(1):27-32.

Souza ZM, Barbieri DM, Junior JM, Pereira GT, Campos MCC (2007) Influência da variabilidade espacial de atributos químicos de um latossolo na aplicação de insumos para cultura de cana-deaçúcar. Ciência e Agrotecnologia 31(2):371-377.

Thorburn P, Biggs J, Webster A, Biggs I (2011) An improved way to determine nitrogen fertiliser requirements of sugarcane crops to meet global environmental challenges. Plant and Soil 339(1):51-67.

Wang X, Shen J, Liao H (2010) Acquisition or utilization, which is more critical for enhancing phosphorus efficiency in modern crops? Plant Science 179(4):302-306.

Wissuwa M, Mazzola M, Picard C (2009) Novel approaches in plant breeding for rhizosphere-related traits. Plant and soil 321(1-2):409-430. 